
and Allied Sciences (IJBPAS) 'A Bridge Betueen caboratory and QRendo'

www.ijbpas.com

\title{
ISOLATION OF PIGMENT PRODUCING HALOPHILIC BACTERIA FROM MARAKKANAM SALT PAN
}

\author{
GEJALAKSHMI A, VIGNESHWARI J, DINESH KUMAR K AND SENTHILKUMAR PK* \\ Department of microbiology, Annamalai University, Annamalai Nagar - 608002, Tamilnadu, India
}

*Corresponding Author: Senthilkumar PK; E Mail: drpks1980@gmail.com

Received 22 ${ }^{\text {nd }}$ July 2021; Revised $25^{\text {th }}$ Aug. 2021; Accepted $30^{\text {th }}$ Sept. 2021; Available online $1^{\text {st }}$ Nov. 2021

https://doi.org/10.31032/IJBPAS/2021/10.11.1075

\begin{abstract}
Halophilic bacteria is grown in high saline condition and sources of industrial and pharmaceutical purpose. The aim of this research work is extraction of pigments from halophilic bacteria is isolated from marakanam salt pan. Soil is the potential source for halophilic bacteria and its grown in halophilic agar media with supplement of $\mathrm{NaCl}$ concentrations. The strains MS1 and MS2 produced the light orange and pale yellow color pigments. Pigments produced strains were identified by morphological. Biochemical and microscopical characterization were recorded.
\end{abstract}

Keywords: Halophilic bacteria, Pigments, Saltpan, Pharmaceutical, Soil INTRODUCTION

Halophiles and halotolerant the absence of salt concentration, which is microorganisms are the two types of one of their distinguishing characteristics. extremeophile microbes. Kushner and The majority of bacterial cells are unable to Larsen were the first to identify halophiles, live in salty environments. The which were later adjusted by Oren based on salt tolerance. Halophiles can thrive in high salinity, while halotolerants can grow in a wide range of salt concentrations. $\mathrm{NaCl}$ having many features prevent from swelling, deformation and osmotic shock. The cells of halophiles do not proliferate in accumulation of large solutes in the cytoplasm region is the key mechanism of this halophile. Sugars, salts, and amino acids are accumulated by other halophiles. The two mechanisms adapt moderate and extreme halophilic microorganisms to hypersaline environments. 
Halophiles are a group of microorganisms that includes bacteria, archaea and fungi. The halophiles are classified into three, based on their salt tolerance: viz, slight halophiles (2-5\% $\mathrm{NaCl})$, moderate halophiles (5-20\% $\mathrm{NaCl}$ ) and extreme halophiles (2030\%) [1]. The halophilic microorganisms differ from other microbial flora by having ability to balance the osmotic pressure and denaturing effects of high salinity. The halophilic microorganisms use two strategies to withstand high salinity existing in the salterns viz., salt-in and salt-out strategy [2].

Colour gives attraction to every marketable product such as food, textiles and pharmaceutical products. Several synthetic colours are available in the market. Due to the adverse effect of the synthetic colourants, nowadays people prefer colourants from natural sources. The demand for the natural pigments is increasing day by day as a result of their health benefits. Though many natural sources are available, microorganisms have proved to be one of the best sources for natural pigments [3] Pigments from extremophilic microorganisms, especially halophilic bacteria proved to be the pool of various group of pigments with attractive colour and bioactivity.
However, most of bacterial pigments are still at the research and development stage. Eventhough, the huge area is under salt production, the halophilic biodiversity in Indian salterns that too particularly the present study site, Markkanam, Tamil Nadu, India are not documented. Therefore, it is essential to study and analyze the biodiversity of this solar saltern which would help us to understand the distribution, physiology and ecological roles of halophilic bacteria. Thus, work on halophilic bacterial pigments production should be intensified to explore novel pigments with unique biological properties and to make them available on the market. Hence, the present study focuses on the solar saltern in Marakkanam, Tamil Nadu, India for novel halophilic bacteria.

\section{MATERIALS AND METHODS}

\section{sample collection}

Soil samples were collected from Marakkanam salt pan (Latitude $12^{\circ} 14^{\circ} 12 \mathrm{~N}$ and Longitude $72^{\circ} 56^{\circ} 28 \mathrm{E}$ ), Tamil Nadu, India using sterile polythene bags randomly at a depth of $10 \mathrm{~cm}$ from the soil surface. The collected samples were stored at $4^{\circ} \mathrm{C}$ for short - term storage or at $-20^{\circ} \mathrm{C}$ for long periods [4].

\section{Isolation of halophilic bacteria}

Halophilic bacteria were isolated 
using selective halophilic agar medium. The samples were serially diluted, an aliquot of $0.1 \mathrm{~mL}$ of each dilution from 10-3 to 10 -6 was taken and spread on the surface of the sterile halophilic agar medium and incubated at $37^{\circ} \mathrm{C}$ for 10 days. After the incubation period, pigmented colonies were selected and purified for further investigation [5].

\section{Morphological And Biochemical Characterization of Halophilic Bacteria}

The halophilic bacteria were subjected to various morphological and biochemical characterization.

Biochemical tests were performed for selected halophilic bacterial isolates were used for all the biochemical tests [6].

\section{Morphological Characterization}

Gram staining

Gram staining was performed for all the halophilic isolates obtained from Marakkanam salt pan, Tamil Nadu, India. Gram stain is a differential stain used to identify Gram positive and Gram negative bacteria. The pigment producing halophilic bacterial isolates were smeared and heat fixed on clean glass slides. The smears were flooded with methyl violet for 1 minute. After washing with distilled water, the smears were flooded with Gram's iodine for 1 minute. Then the smears were decolourised using ethanol for 30 seconds. Finally, the smears were flooded with safranine for 1 minute which acts as a counter stain. The slides were thoroughly and examined under oil immersion in a compound microscope. The morphology of the different pigment producing halophilic bacterial isolates was recorded [7].

\section{Biochemical Characterization}

- The biochemical tests were performed by following the protocol of Bergey manual and the isolates were identified based on Bergey's manual of systematic bacteriology [8].

\section{Extraction Of Pigments From Halophilic}

Bacteria

The pure culture of all pigment producing halophilic bacteria were grown in $100 \mathrm{~mL}$ of halophilic broth was sterilized at $121^{\circ} \mathrm{C}$ under $15 \mathrm{lbs}$ for 20 minutes separately inoculated with selected pigment producing halophilic bacteria and incubated at $37^{\circ} \mathrm{C}$ in an orbital shaker under $150 \mathrm{rpm}$. After three days of incubation, the culture were harvested by centrifugation at 10,000 rpm for $10 \mathrm{~min}$ at room temperature. The pigments were extracted using acetone (intracellular) and ethyl acetate (extracellular) besides the type of pigment produced by the isolates. The extracted Pigment were subjected to dry under Vaccum oven for overnight. The 
dried Pigments were further evaluated for potential analysis [9].

\section{RESULTS}

\section{Collection of soil samples}

Salt pan soil samples were collected by using sterile polythene bags from geographical regions of vilupuram district in Tamil Nadu that locations are Marakanam Region. Soil samples were taken from at the depths of $10 \mathrm{~cm}$ below the surface.

\section{Isolation of halophilic bacteria}

In the present study, sediments samples were collected at the saltern located at Marakkanam area, Villupuram District, Tamil Nadu, India. The samples were collected during the salt production phase and salt harvesting phase. Further, the difference in the color of the salt pan was also noticed between two sampling period. All the three bacterial strains were inoculated on Halophilic agar medium M590 (pH 8.0) for further confirmation of halophilic bacteria. All these isolates grew well in the halophilic media. Pigment producing halophilic bacteria was isolated using halophilic agar medium prepared with distilled water. The plates were incubated for 5-10 days, it showed morphologically different colonies (Figure 1). The isolates obtained from sampling was designated as MSP1 and MSP 2 which MSP denotes Marakkanam Salt Pan.

\section{Morphological characterization}

\section{Colony Morphology}

Halophilic agar plates showing the pale yellow and light orange color colonies. The orange color colonies is opaque and smoothy then pale yellow colonies is slightly mucoid appearance.

\section{Gram staining}

The Gram staining results showed that most of the halophilic bacterial isolates were Gram positive rods, thus the results indicated that most of the halophilic bacteria prevailing in the Marakkanam salt pan, Tamil Nadu, India are Gram positive rods.

\section{Extraction of pigments}

The pigments isolates were cultured in halophilic broth and after 7 days, the cells were separated by centrifugation for pigment extraction. Most of the isolates Produce Bright Yellow, Light Orange, Pink and Pale yellow coloured Pigments (Figure 2). 


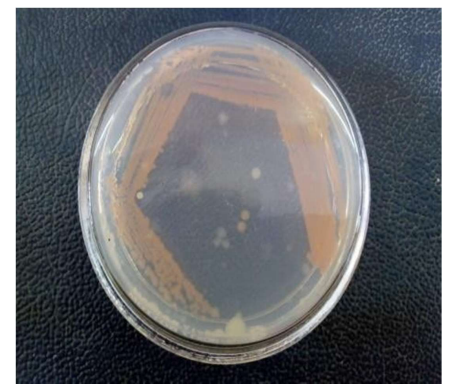

MSP1

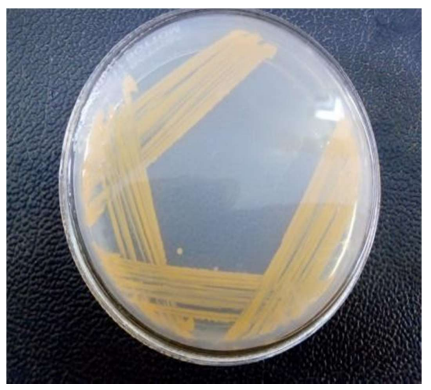

MSP2

Figure 1: Pure culture of Halophilic Bacteria

Table 1: Biochemical Characterization Of Halophilic Bacteria -Ms1 - Ms2

\begin{tabular}{|c|c|c|c|}
\hline S. No. & BIOCHEMICAL TEST & MS1 & MS2 \\
\hline 1. & Indole test & Positive & Negative \\
\hline 2. & Methyl red & Positive & Negative \\
\hline 3. & Voges Proskauer test & Negative & Negative \\
\hline 4. & Citrate utilization & Positive & Positive \\
\hline 5. & Urease test & Negative & Negative \\
\hline 6. & Catalase test & Positive & Positive \\
\hline 7. & Oxidase test & Negative & Positive \\
\hline 8. & Starch hydrolysis & Nehative & Positive \\
\hline
\end{tabular}

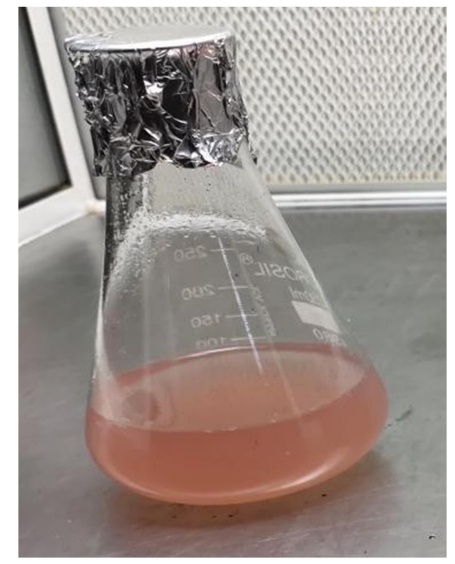

MSP1

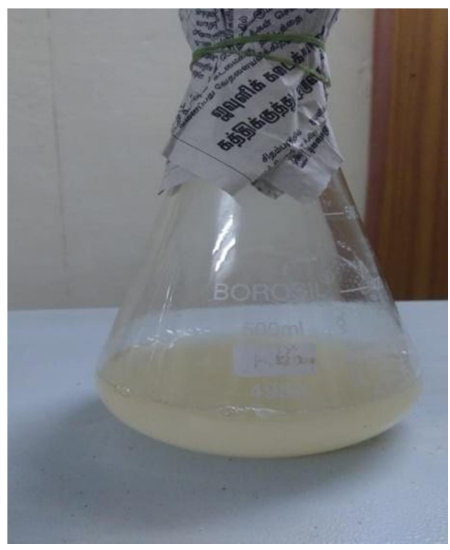

MSP2

Figure 2: Extraction of pigments

\section{DISCUSSION}

Solar salterns are natural or artificial ponds used for salt production and they provide ideal conditions for the growth and multiplication of halotolerant and halophilic microorganisms. In order to cope up with the harsh environmental conditions prevailing in the salterns, halophlilic microbes have several adaptive features such as efficient ion pumps, acidic proteins, internal compatible solutes and UV absorbing pigments. Halobacterium halobium produced the carotenoids pigments are used to against the cell death [10]. The 
pigments of halophilic microorganisms give attractive colouration to the salt pans. Pigments have wide range of applications in food, medical and neutraceutical industries. In the present study, the least explored Marakkanam salt pan, Tamil Nadu, India was investigated for pigment producing halophilic bacteria. In the present study, totally 8 halophilic bacteria were isolated from solar salt pans of Marakkanam. Among them, most of the isolates were pink, pale pink, pale yellow, lemon yellow, creamy, orange and bright orange in colour. Microbial pigments produced canthaxanthin, astaxanthin, prodigisoin, violacein, phycocyanin, $\beta$-carotene, lycopene, and riboflavin were used as food colorants and antioxidant agents. Prathiba 2019 [11] isolated the moderate halophilic bacteria produced the different production of pigments from saline environments it has a high antioxidant activity [12].

\section{CONCLUSION}

In this Study, pigments producing halophilic bacteria were isolated from solar salterns. Since the Isolates MSP1 and MSP2 has an attractive orange and pale yellow Pigment; it could be used in various industrial applications and biotechnological applications.

\section{REFERENCES}

[1] Oren A. Halophilic microorganisms and their environments. Dordrecht, Boston: Kluwer Academic Publishers 2002.

[2] Kushner, D.J. and Kamekura, M., Physiology of halophilic eubacteria. In. 1988

[3] RodríguezValera .Halophilic bacteria, CRC Press, Boca Raton, 109-138

[4] Manikprabhu, D. and Lingappa, K., Actinorhodin a natural and attorney source for synthetic dye to detect acid production of fungi. Saudi J. Biol. Sci., 20: 163-168 microbiol., 2013 53(2):479-484.

[5] Antón J, Oren A, Benlloch S, Rodriguez-Valera F, Amann R, Rossello- novel, extremely halophilic member of the bacteria from saltern Mora R Salini.bacter ruber gen nov., sp nov., a crystallizer ponds. Int J Syst Evol Microbiol . 2002 (52)485-491

[6] Rodriguez-Valera, F., Juez, G. and Kushner, D. J.,. Halocins: saltdependent bacteriocins produced by extremely halophilic rods. Can. J. Microbiol., 198228(1): 151-154

[7] Prescott, L.M., Harley, J.P., Klein, D.A. Microbiology 5th Edn. McGraw-Hill Higher Education, New York. 2005

[8] Gram C., The differential staining of Schizomycetes in tissue sections and in 
dried preparations. Fortschitte der activity. App bio and biotech 2010 .

Medicin, 1884 2: 185-189,

[9] Ventosa A., Quesada E., RodriguezValera F., Ruiz-Berraquero F., RamosCormenzana A., Numerical taxonomy of moderately halophilic Gram-negative rods. Microbiology, 1982128 (9): 1959-1968,

[10]Prathiba, S., \& Jayaraman, G. Evaluation of the anti-oxidant property and cytotoxic potential of the metabolites extracted from the bacterial isolates from mangrove Forest and saltern regions of South India. Preparative Biochemistry and Biotechnology, 2018 48(8), 750-758.

[11]Abbes, M., Baati, H., Guermazi, S., Messina, C., Santulli, A., Gharsallah, N., \& Ammar, E. Biological properties of carotenoids extracted from Halobacterium halobium isolated from a Tunisian solar saltern. BMC Complementary and Alternative Medicine, 2013, 13(1), 13.

[12]Sen, T., Barrow, C. J., \& Deshmukh, S. K. Microbial pigments in the food industry-Challenges and the way forward. Frontiers in Nutrition, 2019 $6(3), 1-14$

[13]Prathiba $S$ and Jayaraman G .Differential production of pigments by halophilic bacteria under the effect of salt and evaluation of their antioxidant 